\title{
THE IMPLEMENTATION OF THE LEARNING CYCLE MODEL FOR THE STUDENTS' LEARNING OUTCOMES IN THE RESEARCH METHODOLOGY
}

\author{
Muh. Anas ${ }^{1}$, Moh. Mulyadi Prasetyo ${ }^{2}$ \\ 1,2STKIP Pembangunan Indonesia \\ 1,2Jalan Inspeksi Kanal Citraland No. 10 Makassar \\ Email: andhys17mmm@gmail.com ${ }^{1}$, mulhands@gmail.com²
}

\begin{abstract}
:
This study aims to determine the application of the Learning Cycle model to the students' learning outcomes of the Research Methodology subjects in the Biology Education department at STKIP Pembangunan Indonesia. This research is a quasiexperimental study with a pretest-posttest control group design. The sample used was 30 students of the Biology department at STKIP Pembangunan Indonesia who programmed Research Methodology. The instruments used were observation sheets and 10 numbers of essay questions. The data analysis techniques are the descriptive statistical analysis and the inferential statistical analysis with the independent sample t-test. Based on the inferential analysis using the independent sample t-test where the p-value of 0.020 is smaller than $0.05(p<0.05)$, it is found that there is an effect of the Learning Cycle model on the students' learning outcomes. Based on the findings of the descriptive statistical analysis, it can be concluded that the application of the Learning Cycle model has an effect on the students' learning outcomes at STKIP Pembangunan Indonesia in the Research Methodology subject with the value range of $85-100$ of 6 students with the percentage of $20 \%$ and the value range of 65 - 84 of 24 students with the percentage of $80 \%$.
\end{abstract}

\begin{abstract}
Abstrak:
Penelitian ini bertujuan untuk mengetahui penerapan model pembelajaran Learning Cycle terhadap hasil belajar mata kuliah Metodologi Penelitian mahasiswa Pendidikan Biologi STKIP Pembangunan Indonesia. Penelitian ini merupakan penelitian Quasi Experimental dengan desain penelitian Pretest-Posttest Control Group Design. Sampel yang digunakan adalah 30 mahasiswa jurusan Biologi STKIP Pembangunan Indonesia yang memprogramkan mata kuliah Metodologi Penelitian. Instrumen yang digunakan adalah lembar observasi dan 10 nomor soal esay. Teknik analisis data yang digunakan adalah analisis statistik deskriptif dan analisis statistik inferensial dengan uji Independent Sampel t-test. Berdasarkan hasil analisis inferensial menggunakan uji Independent Sampel t-test diperoleh nilai $p$ sebesar 0,020 yang lebih kecil dari 0,05 $(p<0,05)$ dengan demikian dapat disimpulkan bahwa ada pengaruh penerapan model pembelajaran Learning Cycle terhadap hasil belajar mahasiswa. Berdasarkan hasil analisis statistic deskriptif dapat disimpulkan bahwa penerapan model pembelajan Learning Cycle mampu meningkatkan hasil belajar mahasiswa STKIP Pembangunan Indonesia pada mata kuliah metodologi penelitian dengan rentang nilai 85 - 100 sebanyak 6 mahasiswa dengan persentase $20 \%$ dan rentang nilai 65 - 84 sebanyak 24 mahasiswa dengan persentase $80 \%$.
\end{abstract}

Keywords:

Learning Cycle Model, Learning Outcomes. 
How to Cite: Anas, M. \& Prasetyo, M. M. (2020). The Implementation of The Learning Cycle Model for The Students' Learning Outcomes in The Research Methodology. Lentera Pendidikan : Jurnal Ilmu Tarbiyah dan Keguruan, 23(2), 209-221. https://doi.org/10.24252/lp.2020v23n2i2.

\section{INTRODUCTION}

Education is one of the efforts that humans can make to improve their quality of life. Every human being needs education to develop his potential which is necessary to live in the society, nation, and state. Education is a process of maturing the students. This understanding is in line with the view from Anwar, Aness, Khizar, \& Nazeer (2012), which is the process of changing the behavior of the students. They become the adult humans who can live independently and as the members of the community in the natural environment around in which the individual live in. The education is all experiences that take place in all environments and throughout life and the education can be interpreted as teaching held on campus as a formal educational institution. Education can take place in the family environment, community environment, and school environment. Family education is also called informal education which is the primary and primary education for a child. Apart from education that takes place in the family environment, education can also take place in the community, which is called non-formal education.

Formal education is an educational path that is tiered and structured. The education process on campus cannot be separated from the role of a lecturer. The lecturers are the determinant factors of the students' learning process success. Therefore, the lecturers must be able to provide good examples and role models for the students. The lecturer can be defined as someone whose job is related to the efforts to educate the nation's life in all aspects, through optimizing the various potentials possessed by the students. The lecturers are the role models for the students so that the lecturers must have good quality standards as the role models for the students. In the learning process, the lecturer must be able to provide a learning that can attract the students' attention. According to Sahin, Cavus, \& Gungoren (2014), the teaching and learning process in class will find many problems, both students' problems, academic problems, and other non-academic problems. All of those problems will have an impact directly or indirectly on the students' learning outcomes. All of those problems must be considered as challenges to achieve the applied learning objectives so that the lecturer needs a strategy in dealing with those problems. One of the learning problems often encountered by the students is their low learning outcomes. The solution that can be offered in overcoming this problem is to improve the learning system.

The learning system should adapt to the needs of the materials being taught. The lecturer should also be able to develop skills in the teaching and learning process to improve the students' quality and achievement. Mastery of the field of study to be taught by a lecturer does not fully guarantee the success of the lecturer in teaching conducted by Acisli, Yalcin, \& Turut (2011). Each lecturer should develop appropriate teaching methods to guide the students to achieve the expected teaching goals. In particular, the lecturers who teach Research Methodology subject are required to teach the research 
methodology material properly, in this case, the mastery of the material and how to choose the appropriate learning method or technique.

Based on the observations in the Biology Education Study Program, only a small proportion of the students, namely about $20 \%$ of students, are actively involved in the learning process. The learning outcomes obtained by the students are different. There are still many students who get low scores below the passing standard, namely a score of 60 in the medium learning outcomes category. The need for the students to understand the material is very important because this Research Methodology subject is very necessary for the preparation of the final project. Therefore, the lecturers are required to be more active, creative, and innovative in delivering the learning materials both from the selection of learning methods and classroom management which will help in achieving the success of the learning process as indicated by learning outcomes that meet the specified competency standards according to Fahri (2014).

When the learning takes place, the students do not pay attention to the lecturer's explanation. It can be seen from some students who chat, disturb others, sit impatiently, and gather in groups to do the assignments. The lecturers also do not provide opportunities to ask the students to develop their thinking potential. Besides, there are no learning activities that make the students active so that the students just stay quiet and listen. According to the research findings conducted by Ruhnisa, Herman, \& Afgani (2017), only a few students did actively answer and no one ask the question if the lecturers conducts questions and answers activities with the students. At the end of the lesson, the lecturer did not conclude the material that had been studied. With such conditions, the learning process shows that it has not been carried out optimally because in the process it has not been able to activate, concentrate, involve, and stimulate the students in fostering their learning interest. Those learning situations make the students less able to explore their abilities in learning.

The Learning Cycle is a learning model with a constructivism approach. Constructivism theory states that the students must discover and manage information in a complex manner, check new information with old rules, and revise it when the rules are no longer appropriate (Fikri, 2014). For the students to understand and be able to apply the knowledge, they must work to solve the problems, find everything for themselves, and try-hard with ideas. According to the constructivism theory, one of the most important principles in educational psychology is that the lecturers do not just impart knowledge to the students (Indah, 2014). The students must build their knowledge in their minds. The lecturers can make this process easier by allowing the students to discover or implement their ideas, and teach the students consciously to use their strategies for learning. The lecturers can provide the students with the steps that bring the students higher understanding, provided that the students themselves have to climb those steps.

According to Balta \& Sarac (2016), the Learning Cycle model was first introduced by Robert Karplus in Science Curriculum Improvement Study/ SCIS. The Learning Cycle is a learning model with a constructivist approach which initially consists of three stages, 
namely: exploration, concept introduction, and concept application. In the next process, the three stages of the cycle are developed. The three cycles are currently being developed into five stages consisting of (a) generating interest, (b) exploration, (c) explanation, (d) elaboration, and (e) evaluation. Gokkurt, (2012) explains that the Learning Cycle model is a learning model that can improve concept development, namely how the knowledge is built in the minds of the students, and the students' skills in finding meaningful knowledge, and linking the old knowledge with the new knowledge and applying it in everyday life.

The Learning Cycle rests on the constructivism as its theoretical foundation. Constructivism is an approach on how the students learn. Karagoz \& Saka (2015) explains, "constructivism is a dynamic and interactive model of how humans learn". The students must be actively involved in the learning activities, where the concept is not directly from the lecturer but it is built by the students themselves. In the early 1960s, Robert Karplus and his colleagues proposed and used an instructional model based on the work in the early 1960s. Furthermore, Robert Karplus and his colleagues proposed and used a learning model based on Piaget's work. This model would eventually be called the Learning Cycle. This model is called the Learning Cycle model. Piaget stated that learning is the development of cognitive aspects which include: structure, content, and function. The intellectual structures are formed in the individuals when they interact with their environment. The structure that is formed makes it easier for the individual to face the increasing demands of his environment. The content is a typical child's behavior pattern that is reflected in the response giving to the various problems or situations it faces. A function is a way that organisms use to make intellectual progress.

The following is an explanation of the five phases in the Learning Cycle according to Balta \& Sarac (2016): Interest Generation, Interest generation stage is the initial stage of the Learning Cycle. At this stage, the lecturer tries to arouse and develop the students' interest and about the topic to be taught. This is conducted by asking questions about factual processes in everyday life (which are related to the topic of discussion). Exploration, exploration is the second stage of the Learning Cycle model. At the exploration stage, small groups of 2-4 students were formed, then allowed to work together in small groups without direct learning from the lecturer. In this group, the students are encouraged to test hypotheses or make new hypotheses, try alternative solutions with a group of friends, and make and record observations and ideas, or opinions that develop in the discussion. Explanation, the explanation is the third stage of the Learning Cycle. At the explanation stage, the lecturers are required to encourage the students to explain a concept with their sentences/ thoughts, ask for evidence and clarification or explanations from the students, and listen critically to each other's explanations between the students or the lecturers. The application phase of the elaboration concept is the fourth stage of the Learning Cycle. In the elaboration stage, the students apply the concepts and skills that have been learned in new situations or different contexts. Thus, the students will be able to learn meaningfully because they have been able to apply the concepts they have just learned in new situations. Evaluation 
Phase, Evaluation is the final stage of the Learning Cycle. At the evaluation stage, the lecturers can observe the students' knowledge or understanding in applying new concepts. The students can do self-evaluation by asking open questions and looking for answers using observations, evidence, and explanations obtained previously. The results of this evaluation can be used by the lecturers as the material for evaluating the application process of the Learning Cycle model that is being applied, whether it is running very well, quite well, or not.

Based on the stages in learning as explained, it is expected that the students will not only listen the lecturers' information but can play an active role in exploring, analyzing, and evaluating their understanding of the concepts being studied. The fundamental difference between the Learning Cycle model and conventional learning is that the lecturers ask more questions than they tell. For example, when researching a problem, the lecturer does not give instructions on the steps that the students must take, but the lecturer asks guiding questions about what the students will do, and what are the reasons the students plan or decide on such treatment. Thus, the students' analytical, evaluation, and argumentative skills can develop and improve significantly.

Considering the dimension of the lecturers, the application of learning provides an advantage because it encourages the lecturers to broaden their horizons and be more creative in planning lessons. Whereas in the terms of students, the application of the Learning Cycle will provide the advantage of increasing learning motivation because the students are actively involved in the learning process. Helping to develop the students' scientific attitude, learning is more meaningful. Besides the advantages possessed by the Learning Cycle model it also has disadvantages. The shortcomings of implementing the Learning Cycle in learning include low learning effectiveness if the lecturer does not master the material and learning steps, Demands the seriousness and creativity of the lecturer in designing and implementing the learning process, requires a more planned and organized classroom management.

Based on the formulation of the problem, the research question is whether the Learning Cycle model has an effect on the learning outcomes of the Biology Education students' Research Methodology at STKIP Pembangunan Indonesia. The purpose of this research is to determine the effect of the Learning Cycle model on the students' learning outcomes of the Research Methodology subject for Biology Education students at STKIP Pembangunan Indonesia with the research hypothesis, namely the Learning Cycle model has an effect on the learning outcomes of the Research Methodology subject for the Biology Education students of STKIP Pembangunan Indonesia.

\section{RESEARCH METHOD}

This research is a quasi-experimental which aims to determine the effect of the Learning Cycle model on the students' learning outcomes in the Research Methodology subject. The sample used was the Biology Education Department students who programmed Research Methodology subject. In this study, the researcher used research instruments in the form of tests, observation sheets, and questionnaires. The instruments 
were described as follows: (1) the observation sheet was designed based on the learning indicators to be achieved, where this observation sheet aimed to see how the students learning process affected the ability to understand concepts and students' learning outcomes and see the students' activity during the learning process using the LC 5E learning model in the Research Methodology class. (2) Test sheet was designed to refer to the indicators set in the RPS and SAP and also according to the indicators of understanding the concept of the Research Methodology class. The test sheet is in the form essay questions totaling 10 numbers. This test sheet has previously been subjected to the expert guidance and validation

The operational definition in this study is the Learning Cycle model, which is a learning model used by the lecturers which consist of five phases, namely engagement, exploration, explanation, elaboration, and evaluation. The learning outcomes are the scores that indicate the level of understanding and mastery of the students from the provision of the learning outcomes tests. The data collection techniques were carried out in the experimental class by providing pretest and posttest instruments. The pretest was carried out including the initial learning outcome test which was integrated with the metacognition skill test and the posttest was carried out including the final achievement test which was integrated with the metacognition skill test. The procedure for this research is to conduct an evaluation test (pretest) before applying the Learning Cycle model, then compare it with the learning outcome evaluation test after implementing the Learning Cycle (Posttest) model.

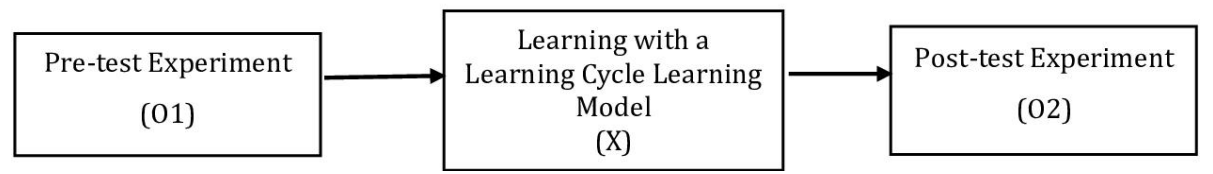

Figure 1. The Research Design Model Adopted from Arikunto (2003)

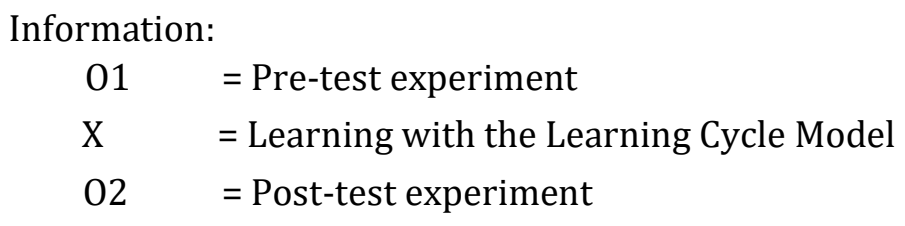

The data analysis technique was the research results in the form of metacognition skills scores and cognitive learning outcomes. They were analyzed by descriptive analysis and inferential analysis. The descriptive analysis was used to describe the learning outcomes obtained from the students. This analysis was also used to describe the students' metacognition skills. The formula was used to calculate the value of the students' learning outcomes. In this study, descriptive statistics namely mean, median, mode, variance, and standard deviation, aimed to see the description of the data obtained. For the inferential statistics, a paired sample t-test was used, where this test was used to test the hypothesis in this study. There is also the following formula adopted from Arikunto (2003): 


$$
t=\frac{b}{s_{b / \sqrt{n}}}
$$

Where:

$\mathrm{t} \quad=$ Value of $\mathrm{t}$ count

$\mathrm{b} \quad=$ Difference between post-test and pre-test

$\mathrm{sb} \quad=$ Standard deviation of the difference between post-test and pretest

\section{RESULTS AND DISCUSSION}

The material taught in the Research Methodology subject is about research models: Quantitative Research, Qualitative Research, Classroom Action Research (CAR), explain about research problems and variables, and compose Structure/systematics and content of the research proposal. The stages carried out in this study are the planning stage, at this stage, the researchers prepare several things, namely SAP and RPS, the student activity sheets, the student activity observation sheets, and the final test questions. After that, the research instrument was validated by 2 validators, namely the expert lecturers who were competent in their fields. The learning activities are divided into three stages, namely the initial activities, the core activities, and the final activities of these stages based on the RPS prepared. The first stage is the preliminary stage, at the beginning of learning the lecturer started with greetings and prayers. Furthermore, the lecturer gave questions as an apperception to the students to check their understanding of the type of the research material. The lecturer showed some examples of titles of research and asked the students "what is the type of this research? After the students answered the questions and had a little idea of what they would learn in the Research Methodology subject then, the lecturer conveyed the learning objectives to be achieved, namely the students are expected to have knowledge of the research methodologies such as being able to explain research problems and variables, determine the type of research they will use, determine research samples, data collection techniques, analysis used, and compile the report structure research.

The second stage is the exploration stage. At this stage, the lecturer conducted questions and answers and presented the information to the students regarding research methodology materials and the lecturer digged up the information from the students' reading results by giving question, "After you know the type of research, what kind of research will you take as your final project? Furthermore, the lecturer divided the students into 4 groups and distributed LKPD. When answering at LKPD, the students were confused about filling in because they were not used to learning like that and were still confused when determining the type of the research, and the lecturer was only a facilitator and motivated the students the purpose of this stage to check the students' understanding. In the third stage, namely the explanation stage, the lecturer as the organizer of the discussion asked the students to explain the concept with their language or thoughts, the goal was to see whether the students could really understand the concept or just memorize it, and conveyed the results of the discussion on problems 1 
and 2 in LKPD. It seems that the students could not answer with they understand and still memorized the formula and the students also looked afraid to answer. Because there are still many students who are confused, the lecturer answered and explained the concept and conveying the results of the discussion on problems 1 and 2 in the LKPD.

The next stage is the stage of applying the concept, this stage is designed to help the students build a broader understanding of the concepts that have been explained. After the students received an explanation from the lecturer and students already understood, then the students expanded the concept by solving questions related to everyday life. At this stage, the lecturer expected that the students can understand the questions and solved the problems using the definitions that had been obtained previously. After the students finished answering and the lecturer asked all groups to present the results of their group discussions with work visits by displaying the results of the discussion on the wall, then one of the group members was asked to explain if other groups asked questions. The students' learning outcomes data were analyzed using evaluation tests in the form of pretest and posttest.

The results obtained are as follows: based on the results of the inferential analysis using the Independent Sample t-test where the p-value is obtained of 0.020 which is smaller than $0.05(\mathrm{p}<0.05)$, it can be concluded that there is an effect of the application of the learning model cycle towards the students' learning outcomes. Based on the results of the descriptive statistical analysis of Learning Outcomes before the application of the Learning Cycle (pretest) model, based on the value of the learning outcomes of 30 students using the Learning Cycle model, the average value is 49.47 , the maximum value is 56 , the minimum value is 36 , the mode score is 48 , and the median value is 48 . Based on the above students' learning outcomes, it can be categorized as in table1 below.

Table 1. The Learning Outcomes Category before the Application of the Learning Cycle Model.

\begin{tabular}{|c|c|c|c|c|}
\hline No & Interval & Category & Frequency & Percentage \\
\hline 1 & $85-100$ & Very high & 0 & $0 \%$ \\
\hline 2 & $65-84$ & High & 0 & $0 \%$ \\
\hline 3 & $55-64$ & Medium & 6 & $20 \%$ \\
\hline 4 & $35-54$ & Low & 24 & $80 \%$ \\
\hline 5 & $0-34$ & Very low & 0 & $0 \%$ \\
\hline \multicolumn{3}{|c|}{ Total } & 30 & $100 \%$ \\
\hline
\end{tabular}

Based on table 1, it can be seen that the scores of 85-100 are included in the very high category, and the frequency does not exist. The scores of 65-84 are included in the high category, and the frequency does not exist. The scores of 55-64 are included in the medium category, and the frequency achieved is 6 out of 30 students with the percentage of $20 \%$. The scores of 35-54 are included in the low category, and the frequency achieved is 24 out of 30 with the percentage of $80 \%$. Meanwhile, the scores of $0-34$ are included in the very low category, and the frequency does not exist. The learning outcomes after the application of the Learning Cycle model (Post-test) show that based on the value of the 
learning outcomes of 30 students using the Learning Cycle model, the average value is 80.40 , the maximum value is 92 , the minimum value is 72 , the mode score is 80 , and the median value is 80 . Those data are categorized in table 2 below.

Table 2. Learning Outcomes Category after the Application of the Learning Cycle Model

\begin{tabular}{ccccc}
\hline No & Interval & Category & Frequency & Percentage \\
\hline 1 & $85-100$ & Very High & 6 & $20 \%$ \\
\hline 2 & $65-84$ & High & 24 & $80 \%$ \\
\hline 3 & $55-64$ & Medium & 0 & $0 \%$ \\
\hline 4 & $35-54$ & Low & 0 & $0 \%$ \\
\hline 5 & $0-34$ & Very low & 0 & $0 \%$ \\
\hline \multicolumn{7}{r}{ Total } & & 30 & $100 \%$ \\
\hline
\end{tabular}

Based on table 2 above, it can be seen that the scores of 85-100 are included in the very high category of the frequency as many as 6 students out of 30 students with the percentage of $20 \%$. The scores of $65-84$ are included in the good category of the frequency as many as 24 out of 30 students with the percentage of $80 \%$. The scores of 55-64 are included in the medium category, and the frequency does not exist. The scores of 35-54 are included in the low category, and the frequency does not exist. Meanwhile, the scores of 0-34 are included in the very low category, and the frequency does not exist.

Based on the learning outcomes obtained from the pre-test, the results obtained in table 1 represent that the students learning outcomes with the score of 85-100 are included in the very high category and the frequency does not exist. The scores of 65-84 are included in the good category then the frequency does not exist. Toward the scores of 55-64, they are included in the medium category as well as the frequency achieved 6 out of 30 students with the percentage of $20 \%$. The scores of 35-54 are included in the low category and the frequency achieved is 24 out of 30 with the percentage of $80 \%$. Meanwhile, the scores of 0-34 are included in the very low category, and the frequency does not exist. Based on the data, it shows that before the application of the Learning Cycle model the average score of the students is $60 \%$ in the low category. This is due to the students in learning did not understand the theory. After all, the learning process is still monotonous without using the Learning Cycle model so that the students' thinking skill is less developed. The findings of this study are in line with the research concept conducted by Trianto in Mulyadi (2017) concerning low learning outcomes, where the classical learning process tends to be teacher-centered that impacts the students be more passive. In that case, the students were not taught the learning strategies, do not understand the materials, and how to think and motivate themselves.

Based on the learning outcomes from the post-test shown in table 2, it can be seen that for the students learning case at STKIP Pembangunan, the average value of the learning outcomes is $85-100$ which is included in the very high category with the frequency of 6 out of 30 students with the percentage of $20 \%$. The scores of $65-84$ are included in the good category, and the frequency is 24 out of 30 students with the 
percentage of $80 \%$. The scores of 55-64 are included in the medium category, and the frequency does not exist, while the scores of 35-54 are included in the low category, and the frequency does not exist. Meanwhile, the scores of 0-34 are included in the very low category, and the frequency does not exist. When it is compared from the data obtained, the average score in the control class with the very high category is not achieved by the students, while in the experimental class, the scores of the very high category were obtained by 6 students. It is indicated that the students' learning outcomes after the application of the Learning Cycle model have improved.

The Learning Cycle model has five phases called 5E that stands for Engagement which aims to prepare the lessons to be conducted in going through the next phase by exploring the students' initial knowledge and ideas and knowing the possibility of misconceptions in previous learning. In the engagement phase, the students' curiosity and the learning interest to be taught are tried to be awakened. In this phase, the learning is invited to make predictions about the phenomena that will be studied and proven in the exploration stage. At this stage, the students are encouraged to ask questions about factual processes in everyday life. The next phase is Exploration. In this phase, the lecturers explore the initial concepts of the students by making observations, taking notes, then communicate them. The variables that were found, controlled, interpreted, are then assumed and inferred with the students.

At the exploration stage, small groups of 2-6 students were formed, then allowed to work together in small groups without direct learning from the lecturer. In this group, the students are encouraged to test hypotheses and/or create new hypotheses, try alternative solutions with their group mates, and carry out and record observations and ideas or opinions that are developed in the discussion. In this stage, the lecturer acts as a facilitator and motivator. This stage aims to check the knowledge that the students have whether it is correct, still wrong, or maybe partially wrong, or partly true. This phase is in line with the integrated teaching materials that present the material. According to Lawson, at this stage, the students learn through their actions and reactions in new situations.

The explanation is the third stage of the Learning Cycle. In the explanation stage, the lecturer is required to encourage the students to explain the concept with their groups/thoughts, ask for evidence and clarification of the students explanations, and listen critically to each other's explanations between the students or the lecturers. With this discussion, The lecturer provides a definition and explanation of the concepts being discussed, using the previous student's explanation as the discussion design. The lecturer collects information from the students related to their experiences in the exploration stage. Its purpose is to examine, recognize, and explain new concepts. The fourth stage of the Learning Cycle model is elaboration. At this stage, the students apply the concepts and skills that have been learned in new situations or different contexts. Thus, the students will be able to learn meaningfully, because they have been able to apply the concepts that they have just learned in new situations. If this stage can be designed properly by the lecturer, the students' motivation will increase. Increasing student 
learning motivation can certainly encourage an improvement in the students' learning outcomes. The evaluation is the last stage of the Learning Cycle. In the evaluation stage, the lecturer can observe the students' knowledge and understanding in applying new concepts. The students can conduct self-evaluation by asking open-ended questions and searching for answers using observations, evidence, and explanations obtained previously.

Likewise, through self-evaluation, the students will be able to identify the deficiencies or progress in the learning process that has been carried out. The advantages of the Learning Cycle model are as follows: a) increase the learning motivation because the students are actively involved in the learning process; b) the students can receive experiences and be understood by others; c) the students are able to develop individual potentials that are successful and useful, creative, responsible, actualizing, and maximizing themselves against the changes that occur; and d) the learning becomes more meaningful. The findings of the study using the Learning Cycle model in the Research Methodology subject in the experimental group are at the 95\% confidence level $(\alpha=0,05)$ which affect the learning outcomes compared to the control group in the learning using the lecturing method. The learning will be meaningful if the students experience positive activities during the learning. This students' activity can be seen when learning takes place. Based on the observations during the learning process, it appears that the learning atmosphere becomes alive because the students are actively involved in the learning. They seek and find important concepts from the subject matter after reading the textbooks they have. In this case, the lecturer only acts as a facilitator and mediator who plans and organizes activities that can design the students' knowledge so that the learning prioritizes in building the students' knowledge (Akay \& Boz, 2010).

According to the research conducted by Zulchaidar (2017), the research findings show that the percentage of the learning completeness reach the classical completeness criteria, namely $\geq 85 \%$, the LC 5E-based worksheets that have been developed are suitable for using as one of the teaching materials that support the learning. The explanation of this research supports this research that the learning using the Learning Cycle model in the Research Methodology subject has a good influence on the success of the students in the cognitive learning. Thus in the students, there has been meaningful learning. This is following the theory of constructivism which emphasizes the development of concepts and deep understanding. If a person does not actively construct his knowledge, his knowledge will not develop. Based on the explanation above, it shows that the different treatments cause different outcomes between the experimental group taught using the Learning Cycle model and the control group taught using the conventional learning model namely lecturing model.

\section{CONCLUSION}

Based on the results of the inferential analysis using the independent sample t-test, where the $p$-value of 0.020 is less than $0.05(\mathrm{p}<0.05)$, it can be concluded that there is an effect of the application of the Learning Cycle model on the students' learning outcomes, 
while, from the results of the descriptive statistical analysis, it can be concluded that the application of the Learning Cycle model can improve the srudents' learning outcomes at STKIP Pembangunan with the value range of $85-100$ as many as 6 students with the percentage of $20 \%$ and the value range of $65-84$ as many as 24 students with the percentage of $80 \%$.

\section{REFERENCES}

Acisli, S. A., Yalcin, \& Turgut. (2011). Effects Of the 5E Learning Model On Students' Academic achievements in movement and force issues. Procedia Social and Behavioral Sciences, 15(1). https://doi.org/https://doi.org/10.1016/j.sbspro.2011.04.128.

Akay, H., \& Boz, N. (2010). The Effect of Problem Posing Oriented Analyses-II subject on the Attitudes toward Mathematics and Mathematics Self-Efficacy of Elementary Prospective Mathematics Teachers. Australian Journal of Teacher Education, 35(1), 59-75. https://doi.org/10.14221/ajte.2010v35n1.6.

Anwar, M. N., Aness, M., Khizar, A., Naseer, M., \& Muhammad, G. (2012). Relationship of Creative Thinking with the Academic Achievements of Secondary School Students. International Interdisciplinary Journal of Education, 1(3), 1-4. file://C:/Users/PC/Downloads/Documents/IIJE_01_03_12.pdf.

Arikunto, S. (2003). Prosedur Penelitian Suatu Pendekatan Praktik. Jakarta: Rineka Cipta.

Balta, \& Sarac, H. (2016). The Effect of 7E Learning Cycle on Learning in Science Teaching: A Meta-Analysis Study. European Journal of Educational Research, 5(2), 61-72. https://doi.org/10.12973/eu-jer.5.2.61.

Fahri, M. B. P. (2014). Penerapan Model Problem Based Learning (PBL) Untuk Meningkatkan Hasil Belajar Siswa Pada Materi Panjang Garis Singgung Persekutuan Dua Lingkaran di Kelas VIII SMP Negeri 19 Palu. Jurnal Elektronik $\begin{array}{llll}\text { Pendidikan Matematika 2(1), Tadulako, } & \end{array}$ http://jurnal.untad.ac.id/jurnal/index.php/JEPMT/article/view/3232.

Fikri, B. M. (2014). Penerapan Model Pembelajaran Problem Based Learning Untuk Meningkatkan Hasil Belajar Siswa Kelas VIII SMP Negeri 4 Palu Pada Materi Prisma. Jurnal Elektronik Pendidikan Matematika Tadulako, 2(1), 45-54. http://jurnal.untad.ac.id/jurnal/index.php/JEPMT/article/view/3230.

Indah, N. F. (2014). Perbandingan Hasil Belajar Kimia dengan Model Pembelajaran Inquiry dan Learning Cycle 5E pada Materi Kelarutan dan Hasil Kali Kelarutan. Jurnal Pendidikan Sains, 4(2), 193-199. https://materikimia.com/wpcontent/uploads/2018/04/Perbandingan-Hasil-Belajar-Kimia-dengan-ModelPembelajaran-Inquiry-dan-Learning-Cycle-5E.pdf.

Karagoz, O., \& Saka, A. Z. (2015). Development of Teacher Guidance Materials Based on 7E Learning Method in Virtual Laboratory Environment. Procedia Social dan Behavioral Sciences, 191, 810-827. https://doi.org/10.1016/j.sbspro.2015.04.524.

Mulyadi, M. P. (2017). Pengaruh pemanfaatan internet (e-learning) terhadap hasil belajar biologi. Universitas Islam Negeri Alauddin Makassar.

Ruhnisa., Herman, T., \& Afgani, J. D. (2017). Pegaruh penggunaan model daur belajar (learning cycle) terhadap kemampuan berpikir kritis dan sikap siswa kelas XI MA 
Muallimat NW Pancor pada mata pelajaran Matematika. Jurnal Education, 2(4), 73-83. https://doi.org/http://dx.doi.org/10.12928/ijeme.v1i1.5698.

Sahin, C., Cavus, S., \& Gungoren, S. (2014). Examining Usage Trends oc Computer Support of the Prospective Primary Scholl Teachers in the Science Education Based on the 5E Model. Procedia Social and Behavioral Sciences, 116, 1913-1918. https://www.sciencedirect.com/science/article/pii/S1877042814005114.

Zulchaidar, I. (2017). Penerapan Strategi Pembelajaran Learning Cycle Tipe 5E dalam Pembelajaran IPA. Jurnal Penelitian Pendidikan, 2(1), 37-40. https://doi.org/10.15294/jpp.v34i2.10798. 